\title{
Adoption of complementary climate-smart agricultural technologies: lessons from Lushoto in Tanzania
}

Maurice Juma Ogada ${ }^{1 *} \mathbb{D}$, Maren Radeny ${ }^{2}$, John Recha ${ }^{2}$ and Solomon Dawit ${ }^{2}$

\begin{abstract}
Background: Agriculture is important for economic growth and development in many countries in Sub-Saharan Africa, including Tanzania. However, agricultural production and productivity remain relatively low, with significant yield gaps attributed to factors such as limited access to and low adoption of appropriate agricultural technologies, and climate-related risks resulting from climate variability and change. This paper explores the drivers of adoption of climate-smart agricultural (CSA) technologies and practices, taking into account the complementarity among agricultural technologies and heterogeneity of the farm households, using data from Lushoto in Tanzania.

Methods: We use a Multivariate Probit analysis of cross-sectional data collected from 264 smallholder farmers in Lushoto-a climate hotspot in Tanzania-to understand the drivers of household decisions to adopt CSA technologies and practices. The technologies included diversification of multiple stress (drought, floods, pests, diseases)tolerant crop varieties, use of fertilizers, and application of herbicides and pesticides. The Multivariate Probit model was preferred as it takes into account the inter-relationships of the technologies as well as heterogeneity of the smallholder farmers for more robust estimates. The independent variables used in the analysis included household socio-economic factors such as the relative importance of crop and livestock enterprises, household land size, social capital, access to agricultural credit and weather information, previous experience with fertilizer use and household characteristics (age, education and gender of household head, and household size).
\end{abstract}

Results: About 63\% of the households diversified their crop enterprises, shifting to improved resilient crops and crop varieties. Another 37\% adopted fertilizers, while 38\% applied pesticides and herbicides. Conditional on the unobservable heterogeneity effects, the results show that household adoption decisions on diversification of multiple stresstolerant crops and crop varieties, fertilizer, and pesticides and herbicides are complementary. In addition, the results confirm existence of unobserved heterogeneity effects leading to varying impact of the explanatory variables on adoption decisions among farmers with similar observable characteristics.

Conclusions: The findings indicate that any effective CSA technology adoption and diffusion strategies and policies should take into account the complementarity of the technologies and heterogeneity of the smallholder farmers. Therefore, inter-related technologies should be promoted as a package or bundled while taking into consideration household and farm-level constraints to adoption.

Keywords: CSA Technology Adoption, Technology Complementarity, Multivariate Probit, Tanzania

*Correspondence: ogadajuma@yahoo.co.uk

1 School of Business, Economics and Social Sciences, Taita Taveta University, P.O. Box 635-80300, Voi, Kenya

Full list of author information is available at the end of the article

(c) The Author(s) 2021. This article is licensed under a Creative Commons Attribution 4.0 International License, which permits use, sharing, adaptation, distribution and reproduction in any medium or format, as long as you give appropriate credit to the original author(s) and the source, provide a link to the Creative Commons licence, and indicate if changes were made. The images or other third party material in this article are included in the article's Creative Commons licence, unless indicated otherwise in a credit line to the material. If material is not included in the article's Creative Commons licence and your intended use is not permitted by statutory regulation or exceeds the permitted use, you will need to obtain permission directly from the copyright holder. To view a copy of this licence, visit http://creativeco mmons.org/licenses/by/4.0/. The Creative Commons Public Domain Dedication waiver (http://creativecommons.org/publicdomain/ zero/1.0/) applies to the data made available in this article, unless otherwise stated in a credit line to the data. 


\section{Background}

Agriculture is important for economic growth and development in many countries in Sub-Saharan Africa, including Tanzania. Through the Comprehensive African Agriculture Development Programme (CAADP) that aims to stimulate agriculture-led development to eliminate hunger and reduce poverty and food insecurity, African Governments have committed to increase public investment in agriculture to $10 \%$ of their annual national budgets and to raise and maintain agricultural productivity and annual growth by at least $6 \%$ [1]. In Tanzania, agriculture contributes $28 \%$ of the country's GDP, provides $95 \%$ of all food and employs over $75 \%$ of the national work force [2]. In a country, where $75 \%$ of the population lives in rural areas, and $80 \%$ is engaged in agriculture, agricultural development is important not only for food security and economic growth but also for poverty reduction. The growth rate of the agriculture sector (4-5\% p.a), however, has remained below the national and CAADP targets (6-10\% p.a). Thus, accelerating development in the agriculture sector is a matter of urgency and priority for both state and non-state sector players in Tanzania.

Climate change and variability are among the critical factors affecting agricultural development adversely in Tanzania, as most of agriculture is rainfed and highly vulnerable. Rising temperatures are already evident, not just in Tanzania but also in the East Africa region. For the last three decades, mean annual temperature has increased at the rate of $0.29^{\circ} \mathrm{C}$ per decade [3]. While short rains have remained relatively stable, long rains, especially in the north, exhibit a declining trend [4]. Delayed onset of rains and increased frequency, length and intensity of droughts have also been observed [5]. Overall projections show that the country will experience temperature rise of between $1.4{ }^{\circ} \mathrm{C}$ and $4.2{ }^{\circ} \mathrm{C}$ [3]. Frequency and severity of extreme weather events such as floods, droughts, and rainstorms are expected to increase over the entire East Africa and this, coupled with increase in outbreak of pest and disease, will reduce agricultural yields [6,7]. This is likely to be more devastating to the poor who rely heavily on rainfed agriculture and have low adaptive capacity [8], leading to worsening poverty and food security indicators [9]. Thus, it is imperative that these farmers transition to agricultural technologies, practices and innovations that enhance their resilience and climate risk management in terms of ecology and socio-economics [10].

Some of the strategies that farmers use to cope with climate change include diversification into improved resilient crop varieties and livestock breeds, soil and land management technologies, water conservation, and improved fodder production and livestock feeding technologies [11-13]. These technologies and practices, collectively referred to as climate-smart agriculture (CSA) technologies, increase productivity, enhance adaptive capacity, and food and nutritional security of the farming households, and contribute to climate change mitigation [14]. CSA approach to agricultural development has three major objectives: (i) sustainably increasing agricultural productivity and incomes; (ii) adapting and building resilience of food systems to climate change; and (iii) reducing greenhouse gas (GHG) emissions from agriculture, where possible $[15,16]$. At the farm level, CSA is closely aligned with sustainable intensification [17]. CSA actions in food systems involve achieving different synergies and trade-offs for productivity, adaptation and mitigation pillars [18]. In general, use of CSA technologies and practices that address any two pillars in a given agroecological zone is considered climate-smart.

Agriculture has potential to contribute to climate change mitigation globally. However, the threat of food insecurity due to climate change raises the question of how much agriculture should contribute to global mitigation targets, if at all [19]. Developing countries, especially those most vulnerable to climate change, such as Tanzania, are focused on adapting to climate change to produce sufficient food, rather than reducing it. Therefore, low emissions development (LED) is the emerging paradigm for mitigation in agriculture in developing countries, defined as sustainably advancing human well-being and agroecological productivity and sustainability in ways that also reduce agricultural GHG emissions [19]. Reductions in emissions should be compared to what emissions otherwise would have been with conventional agricultural development or based on the projection of current practices. LED puts the need to produce food and other goods for human needs first, and mitigation second [20], therefore, differing from mitigation-driven approaches.

To increase uptake, the CSA technologies and practices need to be appropriate for local ecological, climatic, socio-economic and cultural conditions, and the farmers need to be equipped with relevant knowledge and skills to use these technologies [21]. It is for this reason that the CGIAR Research Program on Climate Change, Agriculture and Food Security (CCAFS), in partnership with other stakeholders, has been piloting the ClimateSmart Villages (CSVs) approach in East Africa to help farmers respond to climate variability and change. The CSVs in East Africa have been described in detail in previous studies, including the various CSA technologies piloted [22, 23]. There is sufficient evidence that these technologies deliver benefits in terms of improved crop productivity, incomes, and food security to households [24-26]. Besides, a technology such as crop diversification improves resilience and biodiversity on the farm, enhances farm-level soil fertility and helps in control of 
diseases and pests [27]. Substantial climate change mitigation effects have also been observed to arise from these technologies [25], where farmers shift to LED practices, because they best meet their own goals, and minimize GHG emissions per unit of yield (i.e., emissions intensity). Many agricultural development practices already seek to increase input efficiencies, such as efficient use of nitrogen fertilizer to minimize GHG emission. Despite the potential benefits, adoption of most of the CSA technologies remains low and varied across farm households and regions [23, 28-30]. This suggests that farm technology adoption constraints could be associated with the technologies themselves, farmer and farm-level factors, and institutional factors [21]. For example, the LED technologies such as the use of agroforestry take more than 7 years to realise the benefits as shown in a biophysical study in Lushoto [31].

Previous studies show that adoption of CSA and other agricultural technologies may be driven by access to information about the technologies themselves which may be influenced by social capital, distance to agricultural offices, distance to the market, wealth of the household (as measured by land size, household income and livestock ownership), availability of family labour, farmer's perception of the technology (which may be dependent on culture), farmer characteristics, such as gender, age and education, access to agricultural credit, and agroclimatic environment [32-37]. The studies are, however, not unanimous on the direction of effect of these factors. Moreover, the results tend to vary by location and the technology investigated.

For scaling up adoption of CSA technologies in Tanzania and other economies that are heavily dependent on agriculture, through evidence-based policies, it is imperative that the inter-play of factors that influence adoption is clearly understood. Thus, this paper examines the adoption of CSA technologies and practices, using data from Lushoto, a climate hotspot, in Tanzania. Lushoto provides an interesting context because of its diverse agroecology and socio-economic conditions. The paper investigates the multidimensional agricultural technology adoption decisions by smallholder farmers across heterogeneous households. We seek to quantify potential complementarities among CSA technologies and innovations, and the unobserved household heterogeneities. Quantifying complementarities of these technologies and innovations is important, because they are potentially correlated with some of the observable and unobservable drivers of household technology adoption decisions [38, 39]. We focus on crop diversification, usually defined as increasing the number of crops or varieties of the same crop grown by a farm household [24], and supportive technologies, such as use of fertilizers, and application of herbicides and pesticides. Diversification is critical, because it has been predicted that by 2060 , Africa will have had a rapid increase in the number of diversified farms and decrease in specialised farms [21]. It is, thus, not surprising that CCAFS and the Tanzania Agricultural Research Institute (TARI) have deliberately promoted, not just adoption of improved resilient crop varieties but also diversification of the same as a climate-risk management strategy, and for improving household food diversity and adapting and building resilience to climate change. For better outcomes, improved sustainable soil and land management practices such as use of fertilizers, minimum tillage characterised by prudent use of herbicides and pesticides, and improved storage of the harvest through careful use of pesticides to minimize post-harvest losses, and other improved agronomic practices are being promoted alongside crop diversification [21]. Therefore, this study analyses adoption of three complementary CSA technologies: crop diversification, use of fertilizers and application of herbicides and pesticides.

Most of the previous studies have examined adoption of individual CSA technologies, yet some of these technologies are inter-related and/or yield better results when bundled [40]. Such studies are likely to underestimate or overestimate the effects of different factors on household adoption of CSA technologies [41, 42]. Consequently, this study considered simultaneous adoption decisions of the three technologies under consideration.

In the rest of the paper, we explain the methodology used, present and discuss the results of the analysis before drawing conclusions and policy implications.

\section{Methods}

\section{Study area}

As indicated earlier, this study was undertaken in Lushoto, within the Usambara Mountains in Tanzania. Lushoto is a global biodiversity hotspot, characterized by warm and cold humid agro-climatic zones. Farming and tourism are the main economic activities. The altitude ranges from 780 to $2010 \mathrm{~m}$ above sea level. Rainfall is bimodal, ranging from 690 to $1230 \mathrm{~mm}$ per annum. The long rains occur from March to May (MAM), and short rains from October to December (OND). Over the years, the rainfall amounts have been declining [29], and have become highly variable, characterized by intense storms. Soil types vary along the topographic gradient, ranging from limited and shallow soils (Regosols and Lithic Leptosols) on the peaks, to more developed soils (Cutanic Acrisols and Ferralic Cambisols) [43]. The valleys are characterized by alluvial and wet soils (Mollic Gleyic Fluvisols and Fluvic Gleysols). Lushoto is densely populated, with average household landholding size of 0.4 hectares. The 
upper parts are characterized by intensive mixed croplivestock farming, with agro-pastoral practiced on the lower parts. Because of the steep slopes, deforestation and population pressure, soil erosion is endemic. The soils are degraded, with low levels of soil organic carbon, indicating limited nutrient retention capacity [44], and observed deficiencies in phosphorus and nitrogen [45]. Overall, croplands have lost approximately 50\% of soil organic carbon, and 34\% of nitrogen [44]. This, coupled with the high rates of poverty, has made the households highly vulnerable to climate-related risks and climate change.

To help the farmers respond to and cope with climate variability and change, CCAFS in collaboration with TARI and the Lushoto District Council, initiated collective action in seven villages in Lushoto from 2011. The partnership is modelled around CSVs, with the aim of improving local knowledge and understanding of climate risks for more informed decisions in agriculture. The approach provides a platform for researchers, local partners, and farmers to work together to test various CSA technologies and practices, select and apply those suited to their local conditions. The portfolio of CSA technologies includes weather, water, carbon, crop, livestock and knowledge-smart activities and innovations [23]. The overarching goal is to reduce hunger, ensure food and nutritional security and improve household incomes.

\section{Model specification}

For the econometric analysis, we make a stylized assumption that farm households are rational with the objective of maximizing their utility from agricultural technologies and innovations. More often, this utility is captured by agricultural productivity. Increasing agricultural productivity requires multiple technologies and practices. Thus, a farm household faces multidimensional adoption decision problem. A rational household will choose a combination of technologies and practices which maximizes its expected utility. This is the basis of the argument that package (bundled) adoption may be more productive and beneficial to the farmers than independent adoption of the individual technologies and practices [40]. However, pervasive uncertainty about a new technology or practice and binding credit constraints may confound the complementarity argument [46]. Nevertheless, there is sufficient justification to consider farmers' multiple adoption decisions jointly, because they are inter-related and likely to affect each other. Considering that the dependent variables are binary, we use the Multivariate Probit Model (MVPM) for this analysis.

The specification of an MVPM with our three dependent variables is

$$
Y_{i}^{*}=\beta_{i}^{\prime} X_{i}+\mu_{i}, i=1,2,3,
$$

where $Y_{i}^{*}$ is an unobserved variable representing the latent utility of adopting CSA technology $i, \beta_{i}$ is a vector of unknown parameters to be estimated, $X_{i}$ is a vector of observed factors believed to influence household adoption of CSA technology $i, \mu_{i}$ is the error term which is normally distributed with mean of 0 and variance of 1 , and the variance-covariance matrix of the error term is $\sum=\left[\begin{array}{ccc}1 & \rho_{12} & \rho_{13} \\ & 1 & \rho_{23} \\ & & 1\end{array}\right]$. Therefore, the observed binary adoption variable $Y_{i}=1, Y_{i}^{*}>0,0$ otherwise. Thus, the probability that $Y_{i}=y_{i}$, conditioned on parameters $\beta, \sum$, and a set of explanatory variables, $X$ can be expressed as

$$
\begin{aligned}
& \operatorname{Pr}\left[Y_{i}=y_{i}, i=1,2,3 \mid \beta, \sum\right] \\
& =\iiint_{I_{1} I_{2} I_{3}} \Phi\left(z_{1}, z_{2}, z_{3}, \rho_{12}, \rho_{13}, \rho_{23}\right) d z_{3} d z_{2} d z_{1},
\end{aligned}
$$

where $\Phi$ is the density function of the multivariate normal distribution with the mean vector 0 and the variance-covariance matrix $\sum$, while $I_{i}$ is the interval $\left(-\infty, \beta_{i}^{\prime} X_{i}\right)$ if $y_{i}=1$ and $\left(\beta_{i}^{\prime} X_{i}, \infty\right)$ if $y_{i}=0$ (see [47] for details). The model is estimated by maximum likelihood method, using Stata version 16.

\section{Measuring adoption of crop diversification}

Crop diversification may be viewed as introduction of additional crops to the existing cropping system [24]. In this paper, crop diversification is more broadly defined to include substitution of indigenous crop varieties with improved and more resilient crop varieties while broadening the base of the cropping system. The change also integrates improved and efficient crop agronomic management, such as use of fertilizers, and pesticides and herbicides for improved productivity.

Common measures of crop diversity include BergerParker Index, Entropy Index, Herfindahl Index, Margalef Index, Ogive Index, Shannon Index and Simpson Diversity Index. Counting the number of crops grown by the farmer is another most commonly used method. In this study, we use Simpson Index, popularly known as Herfindahl-Hirschman Index (HHI) in economic literature. The preference is informed by the fact that the index has no requirement that the farmers produce all types of crops [48]. The index was computed as follows:

$$
S D I=1-\sum_{1}^{n} p_{i}^{2}
$$


where $p_{i}$ is the proportionate land area under crop $i$ in the gross land area under crops; $n$ is the total number of crops that the household grows.

The score value ranges from 0 to 1 , where 0 means the household is specialised (not undertaking any crop diversification), while 1 means that the household has the maximum possible level of diversification. Thus, all households with the score of 0 were classified as nonadopters, while those with a score above 0 were classified as adopters of diversification of improved resilient crop varieties. For the complementary technologies and/or practices (i.e., fertilizer and pesticides and herbicides), a household is considered an adopter if it is used on 2 or more of the improved resilient crop varieties adopted by the household. This is because these technologies and practices are meant to be supportive of the crop diversification. Thus, their use must also reflect the diversification. Notice that the traditional varieties were no more resilient because of higher susceptibility to diseases and pests, drought, and taking longer to grow and mature for harvest yet the length of growing period (rainy season) was getting shorter and more variable [49].

\section{Data and summary statistics}

The paper uses cross-sectional data collected from 264 households spread across the villages in Lushoto. Information was collected using close-ended questionnaire and included household demographic characteristics, adoption of climate-smart crops and crop varieties, production and consumption of crops and livestock products, sale of farm products, land use management, agroforestry, household sources of food, access to climate and weather information, relative changes in household income and social capital. We provide a summary of the adopters of each technology and how the different technologies are correlated with each other (Table 1).

The results show that about $63 \%$ of the households were diversifying their crop enterprises and shifting to improved resilient crops and crop varieties. Another $37 \%$ were using fertilizers, with $38 \%$ using pesticides/ herbicides. Tetrachoric correlation analysis shows that adoption of crop diversification of improved resilient crops and crop varieties may trigger the use of fertilizers and pesticides/herbicides by farmers. This underscores the notion that profitability of a given CSA technology or practice may depend on adoption of another CSA technology or practice $[39,40,48]$. That is, a given CSA technology may be productive, but it would yield better results when applied together with other complementary technologies or practices. Adoption of the combination of the technologies provides additional insight about perception of the farmers of the profitability of these technologies (Table 2).

It can be observed that, more households adopted the technologies in combinations rather than singly. About $30 \%$ of households simultaneously adopted diversification of improved resilient crop varieties and fertilizer, and only $4 \%$ adopted fertilizer without crop diversification. About 33\% of the households adopted crop diversification with pesticides/herbicides, while only $3 \%$ adopted pesticides/herbicides only. About $25 \%$ of households simultaneously adopted fertilizers and pesticides/herbicides, while $24 \%$ of the households adopted all the three technologies simultaneously. This may suggest that, in the context of Lushoto, using the technologies in combinations could be more profitable. It may further suggest that diversification of improved

Table 2 Level of adoption of the various technologies and/or their combinations

\begin{tabular}{lc}
\hline Technology combinations & $\begin{array}{l}\text { Rate of } \\
\text { adoption }\end{array}$ \\
\hline Crop diversification only & 23 \\
Fertilizer only & 4 \\
Pesticide/herbicides only & 3 \\
Diversification with fertilizer & 30 \\
Diversification with pesticides/herbicides & 33 \\
Fertilizer with pesticides/herbicides & 25 \\
Diversification with fertilizer and pesticides/herbicides & 24 \\
\hline
\end{tabular}

Table 1 Technology adoption rates in the sample

\begin{tabular}{ll}
\hline Agricultural technology and practice & 63 \\
\hline Crop diversification (\%) & 37 \\
Fertilizer in a diversified crop system (\%) & 38 \\
Pesticide/herbicide in a diversified crop system (\%) & $0.504^{* * *}$ \\
Correlation between crop diversification and fertilizer use & $0.564^{* * *}$ \\
Correlation between crop diversification and pesticide/herbicide use & $0.687^{* * *}$ \\
Correlation between fertilizer and pesticide/herbicide use & 264 \\
Number of observations (households) &
\end{tabular}

*** indicate that pairwise correlations are statistically significant at $1 \%$ 
resilient crop varieties, even without fertilizer and pesticides/herbicides, could still be fairly profitable.

Previous studies have found household demographic characteristics, such as gender, age and education of the household head, and household size to be important in influencing agricultural technology adoption decisions (see [50] for details). Other factors that have been found to be correlated with agricultural technology adoption include household land size, household income and/or access to credit and the relative importance of crop and livestock farming. Thus, we include these variables in the empirical model specification. Table 3 provides a brief description of these variables.

About $80 \%$ of the households surveyed were maleheaded, while $20 \%$ were female-headed, with an average household size of 5 . The highest level of education attained was primary for $62 \%$ of households, secondary for $31 \%$ of the households, and post-secondary for $6 \%$ of the households. For about $1 \%$ of the households, no member had any formal education. Average years of schooling was 9. The average household land holding size was 1.99 acres. Crop farming was ranked by households as being more important with a score of $65 \%$, while livestock production had an average score of about $21 \%$. Notably, the households had a modest annual income of about USD 200. In the period of reference, $40 \%$ of the households belonged to farmer groups, with a similar proportion also having access to credit. Weather and climate information was received by $79 \%$ of households.

\section{Results}

The empirical results are presented in Table 4. The highly significant likelihood ratio test shows that the MVP model fits the data better and captures farm technology adoption decisions better than the independent Probit models. This is also evident from the significant error correlation parameters. In a nutshell, the MVP model outperforms the standard univariate model popularly used in technology adoption studies. This shows the presence of complementarity among the CSA technologies and substantial unobserved heterogeneity effects. For comparison, we also present the results of the univariate Probit models for the three technologies under consideration (see Table 4). While the results are consistent with those of MVP in terms of direction of effect, most of the marginal effects are hardly of the same size. Thus, it can be concluded that endogeneity, in this case, leads largely to imprecise estimation of the marginal effects. Thus, we base our interpretations and further discussion on the MVP results.

The contemporaneous error correlations of the MVP model (presented at the bottom of Table 4) are all positive and statistically significant. These are interpreted as the estimates of input complementarities among crop diversification, fertilizer, and pesticides and/herbicides.

Table 3 Variables used in the analysis

\begin{tabular}{|c|c|c|c|}
\hline Variable Name & Variable description & Mean & SD \\
\hline \multicolumn{4}{|l|}{ Outcome Variables } \\
\hline Crop diversification & Dummy $=1$ if household adopts diversification & 0.63 & 0.48 \\
\hline Use of fertilizer & Dummy $=1$ if household uses fertilizer & 0.37 & 0.48 \\
\hline Use of Pesticide/herbicide & Dummy $=1$ if household uses pesticide/herbicide & 0.38 & 0.49 \\
\hline \multicolumn{4}{|l|}{ Household characteristics } \\
\hline Age of household head & Chronological age of household head in years & 51 & 14 \\
\hline Gender of household head & Gender of household head $($ male $=1$ ) & 0.8 & 0.4 \\
\hline Education of household head & Years of schooling of household head & 9 & 2 \\
\hline Household size & No. of household members & 5.5 & 2.0 \\
\hline \multicolumn{4}{|l|}{ Household socio-economic factors } \\
\hline Importance of crop farming & Self-assigned score (out of 10 points) & 6.5 & 1.7 \\
\hline Importance of livestock & Self-assigned score (out of 10 points) & 2.1 & 1.3 \\
\hline Land size & Household land size in acres & 1.99 & 1.15 \\
\hline Income & Self-reported income (in USD) & 198.5 & 362.8 \\
\hline Social capital & Membership of social groups (member $=1$ ) & 0.4 & 0.4 \\
\hline Access to credit & Whether household received credit (received =1) & 0.4 & 0.4 \\
\hline Weather information & Dummy $=1$ if household received weather forecast & 0.79 & 0.4 \\
\hline Previous fertilizer use & Dummy $=1$ if household had previously used fertilizer & 0.21 & 0.4 \\
\hline Number of observations & & 264 & \\
\hline
\end{tabular}

SD stands for standard deviation 
Table 4 Adoption regression results

\begin{tabular}{|c|c|c|c|c|c|c|}
\hline \multirow{2}{*}{$\begin{array}{l}\text { Explanatory } \\
\text { variables }\end{array}$} & \multicolumn{3}{|c|}{ Multivariate probit estimates } & \multicolumn{3}{|c|}{ Univariate probit estimates } \\
\hline & $\begin{array}{l}\text { Crop } \\
\text { diversification }\end{array}$ & Fertilizer & $\begin{array}{l}\text { Pesticide/ } \\
\text { herbicide }\end{array}$ & $\begin{array}{l}\text { Crop } \\
\text { diversification }\end{array}$ & Fertilizer & Pesticide/herbicide \\
\hline \multicolumn{7}{|c|}{ Household characteristics } \\
\hline $\begin{array}{l}\text { Age of household } \\
\text { head }\end{array}$ & $-0.005(0.002)^{* *}$ & $-0.001(0.002)$ & $-0.003(0.002)$ & $-0.004(0.002)^{* *}$ & $-0.001(0.002)$ & $-0.003(0.02)$ \\
\hline $\begin{array}{l}\text { Gender of house- } \\
\text { hold head }\end{array}$ & $0.05(0.08)$ & $0.16(0.07)^{* *}$ & $0.21(0.069)^{* * *}$ & $0.04(0.08)$ & $0.18(0.07)^{* * *}$ & $0.23(0.07)^{* * *}$ \\
\hline $\begin{array}{l}\text { Education of } \\
\text { household head }\end{array}$ & $-0.01(0.01)$ & $0.01(0.01)$ & $-0.02(0.01)^{* *}$ & $-0.01(0.01)$ & $-0.001(0.01)$ & $-0.02(0.01)^{* *}$ \\
\hline Household size & $0.04(0.01)^{* *}$ & $0.03(0.01)^{* *}$ & $0.03(0.014)^{* *}$ & $0.04(0.015)^{* *}$ & $0.03(0.01)^{* *}$ & $0.03(0.01)^{* *}$ \\
\hline \multicolumn{7}{|c|}{ Household Socio-economic factors } \\
\hline $\begin{array}{l}\text { Importance of crop } \\
\text { farming }\end{array}$ & $0.03(0.02)$ & $-0.01(0.02)$ & $0.0002(0.02)$ & $0.02(0.02)$ & $-0.01(0.02)$ & $-0.0001(0.07)$ \\
\hline $\begin{array}{l}\text { Importance of } \\
\text { livestock }\end{array}$ & $0.01(0.03)$ & $-0.03(0.02)$ & $-0.05(0.03)^{*}$ & $0.01(0.03)$ & $-0.03(0.02)$ & $-0.05(0.03)^{* *}$ \\
\hline Land size & $0.10(0.03)^{* * *}$ & $0.06(0.03)^{* *}$ & $0.09(0.03)^{* * *}$ & $0.11(0.03)^{* * *}$ & $0.06(0.03)^{* *}$ & $0.09(0.03)^{* * *}$ \\
\hline Income & $0.01(0.01)$ & $0.01(0.007)^{*}$ & $-0.00(0.01)$ & $0.01(0.01)$ & $0.01(0.007)^{*}$ & $-0.001(0.007)$ \\
\hline Social capital & $-0.01(0.07)$ & $0.08(0.07)$ & $0.09(0.067)$ & $-0.01(0.07)$ & $0.08(0.07)$ & $0.1(0.07)$ \\
\hline Access to credit & $0.02(0.09)$ & $-0.01(0.09)$ & $0.001(0.09)$ & $0.03(0.09)$ & $-0.02(0.09)$ & $-0.01(0.08)$ \\
\hline $\begin{array}{l}\text { Received weather } \\
\text { information }\end{array}$ & $0.21(0.08)^{* * *}$ & $0.05(0.07)$ & $0.14(0.067)^{* *}$ & $0.22(0.08)^{* * *}$ & $0.04(0.07)$ & $0.13(0.07)^{* *}$ \\
\hline $\begin{array}{l}\text { Previous use of } \\
\text { fertilizer }\end{array}$ & & $0.17(0.07)^{* *}$ & & & $0.22(0.08)^{* * *}$ & \\
\hline$\rho_{12}$ & $0.44(0.1)^{* * *}$ & & & & & \\
\hline$\rho_{13}$ & $0.47(0.09)^{* * *}$ & & & & & \\
\hline$\rho_{23}$ & $0.66(0.07)^{* * *}$ & & & & & \\
\hline $\begin{array}{l}\text { Likelihood ratio } \\
\text { test }\end{array}$ & $x^{2}(34)=88.75$ & \multirow{2}{*}{\multicolumn{2}{|c|}{ Prob $>x^{2}=0.0000$}} & & & \\
\hline $\begin{array}{l}\text { Number of obser- } \\
\text { vations }\end{array}$ & 258 & & & & & \\
\hline
\end{tabular}

The results show adoption propensities. Standard errors are in parentheses

${ }^{*},{ }^{*}$, and ${ }^{* * *}$ indicate significance at $10 \%, 5 \%$ and $1 \%$, respectively

There is a very strong complementarity between fertilizer adoption and pesticide/herbicide use (correlation coefficient of 0.66). The correlation between crop diversification and fertilizer adoption (correlation of 0.44) and between crop diversification and pesticides/herbicides use (correlation of 0.47 ) are also fairly strong. These practices are not independent events (Likelihood ratio test being $\left.x^{2}(34)=88.75^{* * *}\right)$.

Estimation results on the other explanatory variables in our CSA technology adoption propensity equations largely show heterogeneity in impact.

a) Age of the farmer, though not correlated with adoption of fertilizer and pesticides/herbicides, is negatively correlated with adoption of crop diversification.

b) Male farmers are more likely to adopt fertilizers and pesticides/herbicides compared to their female counterparts. c) Education level of the farmer, though having no effects on adoption of crop diversification and fertilizer, lowers the probability of adoption of pesticides/ herbicides.

d) Larger households have a higher likelihood of adopting the three technologies, just like the households with larger landholding sizes.

e) Other important predictors of adoption of the technologies under consideration include importance of livestock to the household (which lowers probability of use of pesticides/herbicides), off-farm income (which increases the probability of adoption of fertilizer), access to weather information (which increases probability of adoption of crop diversification and pesticide/herbicide use), and experience with fertilizer use (which increases probability of fertilizer adoption in the subsequent periods). 
In the next section, we discuss these results in detail and compare them with those of previous studies.

\section{Discussion}

The strong correlation between adoption of crop diversification and adoption of fertilizer is most probably because of the anticipated better returns from the joint adoption [50]. It may also be due to the different crops competing for soil nutrients, compelling the farmers to supplement with fertilizers for better yields. Indeed, some previous studies have found diversification to reduce technical efficiency of the farmers and recommend improved soil management techniques under such systems [51]. The complementarity between crop diversification and fertilizer has previously been observed in the maize-legume system in Kenya [52], and could also be attributed to the resultant increased fertilizer use efficiency due to different rooting systems of different crops, leading to uptake of fertilizer nutrients from different soil depths [53]. The strong correlation between fertilizer and pesticides/herbicides adoption is understandable, because the use of fertilizers may also trigger growth of weeds, necessitating the use of herbicides. Furthermore, the potential good harvest associated with use of fertilizer may call for use of pesticides on the stored harvest. Similarly, the complementarity between crop diversification and pesticides could be likely attributed to increased yield, necessitating prolonged storage period which is made possible through pesticides. These results are consistent with those of previous studies in Kenya and SubSaharan Africa [50, 54].

Older farmers have a lower propensity to adopt crop diversification. This could be due reduced access to information regarding the technology, either because this category of farmers is less likely to go out to seek new information, especially is agricultural offices are far from their locations. It may also indicate that younger farmers are more willing to try new innovations unlike older farmers who may be more cautious with new approaches. This is consistent with [34, 36] and [50, 54].

Male farmers are more likely to adopt fertilizers and pesticides/herbicides. However, gender of the farmer has no effect on adoption of crop diversification. The comparative advantage of male farmers in adoption of fertilizer and pesticides/herbicides could be attributed to control of resources, because these technologies, unlike diversification, could be expensive and out of reach of the resource-constrained women farmers. Influence of gender on technology adoption has previously been established [33, 34].

Land size and household size are positively correlated with adoption of the three technologies. It is also possible that larger household size is a source of family labor which is important for crop diversification, and application of both fertilizer and pesticides and/or herbicides. This indicates that farm labour is more expensive to hire and households rely mainly on household labour. Similar findings have previously been established by [34, 36] and $[50,54]$. Households with larger land sizes are more likely to adopt diversified crops, fertilizers and pesticides and/or herbicides. This is not surprising, because more land provides opportunity for the farmer to grow a wide range of crops, and to cut on demand for farm labour, the farmer may rely on herbicides. Because such a farmer may have a large harvest, probability of using pesticides for storage may also increase. Such farmers may also use fertilizers because of the economies of scale or because they are able to leverage finances through, for example, leasing out land.

Households receiving weather forecast information are more likely to adopt MST crop diversification and pesticides and/or herbicides. Perhaps this is because crop diversification and use of herbicides may require better and early planning. To diversify crops, for example, the farmers require to ready a number of seed varieties before the on-set of rains. A farmer who is empowered with weather information and agro-advisories is better placed to do this than his/her counterpart who is not. Finally, a farmer who has previously used fertilizer, is more likely to use it in the subsequent cropping seasons. Most probably this is because the initial use is a chance to experiment and when the farmer updates his/her belief on the good returns due to fertilizer use, he/she is likely to continue using it and even upgrade the intensity of application.

Based on these results, we draw conclusions in the next section.

\section{Conclusions}

The paper analyzed the multidimensional CSA technology adoption decisions in the presence of household heterogeneities. The technologies and practices include diversification of improved resilient crop varieties, fertilizers, and pesticides and/or herbicides. Thus, the paper quantified the complementarities among CSA technologies and practices while controlling for unobserved heterogeneities which might be independent or correlated with the observable explanatory variables which influence household farm technology adoption. Results show that CSA technology adoption decisions exhibit complementarity for the technologies and practices analyzed. Conditional on various observable household level factors and unobservable heterogeneity, we find correlation in adoption propensities among crop diversification, fertilizers, and pesticides and/ or herbicides. We also find evidence of unobserved 
heterogeneity which leads to heterogeneous impact of explanatory variables on adoption of different farm technologies even among farmers with similar observable characteristics. These heterogeneities could represent variations in tastes and preferences among households for individual CSA technologies and practices conditioned by extent of risk aversion or perceived rate of return to technology adoption. This implies that technology diffusion strategies and policies based on the univariate analysis may be insufficient in addressing household CSA technology adoption process, and may contribute to the observed low levels of adoption.

These findings provide critical insights which may be useful in scaling CSA technology adoption and diffusion among smallholder farmers. For example, complementarity among technologies shows that policy instruments that affect one technology are likely to influence other related technologies. Thus, diffusion can be improved by providing and promoting these technologies as a package (bundling). Diffusion could further be enhanced through targeted credit access to poorer households, enhanced farmer experiences through demonstration (e.g., using smart farms), improved access to weather information and agro-advisories, and promoting technologies which are friendly to women, the old and other marginalized groups.

\section{Abbreviations \\ CCAFS: Climate Change, Agriculture and Food Security; CGIAR: Consultative Group in Agricultural Research; CSA: Climate-Smart Agriculture; CSVs: Climate- Smart Villages; MVPM: Multivariate Probit Model; TARI:Tanzania Agricultural Research Institute.}

\section{Acknowledgements}

This work was implemented as part of the CGIAR Research Program on Climate Change, Agriculture and Food Security (CCAFS), which is carried out with support from CGIAR Trust Fund Donors and through bilateral funding agreements. For details, please visit https://ccafs.cgiar.org/donors. The views expressed in this document cannot be taken to reflect the official opinions of these organizations.

\section{Authors' contributions}

All authors variously contributed to the conceptualisation of the study, data analysis, and write up of the manuscript. All authors read and approved the manuscript.

\section{Funding}

The CGIAR Research Program on Climate Change, Agriculture and Food Security (CCAFS) used its own budget for this study.

\section{Availability of data and materials}

The data used in this study are from the household survey conducted in Lushoto, Tanzania and are available on request.

\section{Declarations}

\section{Ethics approval and consent to participate}

This study did not require ethical approval. However, consent to participate was obtained from each respondent of the participating households.

\section{Consent for publication}

All the authors give consent for publication of the article.

\section{Competing interests}

The authors declare that they have no competing interests.

\section{Author details}

${ }^{1}$ School of Business, Economics and Social Sciences, Taita Taveta University, P.O. Box 635-80300, Voi, Kenya. ${ }^{2}$ CGIAR Research Program On Climate Change, Agriculture and Food Security (CCAFS), International Livestock Research Institute (ILRI), P.O. Box 30709-00100, Nairobi, Kenya.

Received: 4 September 2020 Accepted: 8 July 2021

Published online: 11 November 2021

\section{References}

1. NEPAD. New Partnership for Africa's Development. Accelerating CAADP Country Implementation: A guide for Implementers. 2009.https://www. caadp.net/pdf/CAADP-imp-guide-WEB.pdf. Accessed 22 Mar 2021.

2. URT. National agriculture policy. Dar es Salaam: Government Publishing Press. United Republic of Tanzania (URT). 2013.

3. Germany CSC: Climate-Fact-Sheet: Burundi - Malawi - Rwanda-Tanzania; updated version 2015. Hamburg. 2016.

4. Rowell DP, Booth BBB, Nicholson SE, Good P. Reconciling past and future rainfall trends over East Africa. J Clim. 2015;28(24):9768-88.

5. Sieber S, Jha S, Tharayil Shereef A-B, Bringe F, Crewett W, Uckert G, Polreich S, Ndah TH, Graef F, Mueller K. Integrated assessment of sustainable agricultural practices to enhance climate resilience in Morogoro, Tanzania. Reg Environ Change. 2015;15(7):1281-92.

6. IPoCC (IPCC). Climate change 2014: synthesis report. Contribution of Working Groups I, II and III to the Fifth Assessment Report of the Intergovernmental Panel on Climate Change. IPCC, Geneva; 2014.

7. Seneviratne SI, Nicholls N, Easterling D, Goodess CM, Kanae S, Kossin J, Luo Y, Marengo J, Mclnnes K, Rahimi M, et al. Changes in climate extremes and their impacts on the natural physical environment. In: Field CB, Dahe Q, Stocker TF, Barros V, editors., et al., Managing the risks of extreme events and disasters to advance climate change adaptation: special report of the intergovernmental panel on climate change. Cambridge: Cambridge University Press; 2012. p. 109-230.

8. IPoCC: Climate Change (IPCC). Impacts, adaptation, and vulnerability: contribution of working group ii to the third assessment report of the intergovernmental panel on climate change. Cambridge: Cambridge University Press; 2001. p. 2001

9. Thornton P, Karanja S, Jones PG, Mutie I, Herrero M. Genesis reversed: climate change impacts on agriculture and livelihoods in mixed croplivestock systems of East Africa. Nairobi: International Livestock Research Institute; 2011. p. 162.

10. Navigating social-ecological systems. Building resilience for complexity and change. Cambridge: Cambridge University Press; 2002.

11. Babatunde RO, Qaim M. Impact of off-farm income on food security and nutrition in Nigeria. Food Policy. 2010;35(4):303-11.

12. Burney JA, Naylor RL. Smallholder irrigation as a poverty alleviation tool in sub-Saharan Africa. World Dev. 2012;40(1):110-23.

13. Karamba WR, Quiñones EJ, Winters P. Migration and food consumption patterns in Ghana. Food Policy. 2011;36(1):41-53.

14. $\mathrm{FaAO}(\mathrm{FAO})$. Gender dimensions of agricultural and rural employment: differentiated pathways out of poverty; status, trends and gaps. FAO: Rome, Italy. 2010.

15. Lipper L, Thornton P, Campbell BM, Baedeker T, Braimoh A, Bwalya M, Caron P, Cattaneo A, Garrity D, Henry K, et al. Climate-smart agriculture for food security. Nat Clim Chang. 2014;4(12):1068-72.

16. FAO. Climate-smart agriculture sourcebook executive summary. Rome, Italy: FAO. (2013) http://www.fao.org/3/a-i3325e.pdf. Accessed 22 Mar 2021.

17. Campbell BM, Thornton $P$, Zougmoré R, van Asten $P$, Lipper L. Sustainable intensification: what is its role in climate smart agriculture? Curr Opin Environ Sust. 2014;8:39-43. 
18. Vermeulen SJ, Campbell BM, Ingram JSI. Climate change and food systems. Annu Rev Environ Resour. 2012;37(1):195-222.

19. Lini W. The mitigation pillar of climate-smart agriculture (CSA): targets and options. Agric Dev. 2017;30:19-22.

20. Nash J, Costa Junior C, Galford G, Gurwick N, Wollenberg E: Methods for Identifying Low Emissions Development Options in Agriculture. CCAFS Working Paper No 147. . CGIAR Research Programme on Climate Change, Agriculture and Food Security (CCAFS) Copenhagen, Denmark. (2015)

21. Seo SN. Is an integrated farm more resilient against climate change? A micro-econometric analysis of portfolio diversification in African agriculture. Food Policy. 2010;35(1):32-40.

22. Recha J KP, Atakos V, Radeny M, Mungai C Stories of Success: ClimateSmart Villages in East Africa. Wageningen, Netherlands: CGIAR Research Program on Climate Change, Agriculture and Food Security (CCAFS). 2017.

23. Radeny M OM, Recha J, Kimeli P, Rao EJO, Solomon D Uptake and Impact of Climate-Smart Agriculture Technologies and Innovations in East Africa. CCAFS Working Paper no. 251. Wageningen, the Netherlands CGIAR Research Program on Climate Change, Agriculture and Food Security (CCAFS) 2018

24. Makate C, Wang R, Makate M, Mango N. Crop diversification and livelihoods of smallholder farmers in Zimbabwe: adaptive management for environmental change. Springerplus. 2016;5(1):1135.

25. Kimaro AA, Sererya OG, Matata P, Uckert G, Hafner J, Graef F, Sieber S, Rosenstock TS. Understanding the multidimensionality of climate-smartness examples from agroforestry in Tanzania. In: Rosenstock TS, Nowak A, Girvetz E, editors. The Climate-smart agriculture papers investigating the business of a productive resilient and low emission future. Cham: Springer International Publishing ; 2019. p. 153-62.

26. Ogada MJ, Rao EJO, Radeny M, Recha JW, Solomon D. Climate-smart agriculture, household income and asset accumulation among smallholder farmers in the Nyando basin of Kenya. World Dev Perspect. 2020;18:100203

27. Lin BB. Resilience in agriculture through crop diversification: adaptive management for environmental change. Bioscience. 2011;61(3):183-93.

28. Mungai C, Opondo M, Outa G, Nelson V, Nyasimi M, Kimeli P. Uptake of climate-smart agriculture through a gendered intersectionality lens: experiences from Western Kenya. In: Leal Filho W, Belay S, Kalangu J, Menas W, Munishi P, Musiyiwa K, editors. Climate change adaptation in Africa: fostering resilience and capacity to adapt. Cham: Springer International Publishing; 2017. p. 587-601.

29. Nyasimi M, Kimeli P, Sayula G, Radeny M, Kinyangi J, Mungai C. Adoption and dissemination pathways for climate-smart agriculture technologies and practices for climate-resilient livelihoods in Lushoto, Northeast Tanzania. Climate. 2017;5(3):63.

30. Tesfaye K, Kassie M, Cairns JE, Michael M, Stirling C, Abate T, Prasanna BM, Mekuria M, Hailu H, Rahut DB, et al. Potential for Scaling up Climate Smart Agricultural Practices: Examples from Sub-Saharan Africa. In: Leal Filho W, Belay S, Kalangu J, Menas W, Munishi P, Musiyiwa K, editors., et al., Climate Change Adaptation in Africa: Fostering Resilience and Capacity to Adapt. Cham: Springer International Publishing; 2017. p. 185-203.

31. Ambaw G, Recha JW, Nigussie A, Solomon D, Radeny M. Soil carbon sequestration potential of climate-smart villages in east African countries. Climate. 2020;8(11):124.

32. Feder G, Umali DL. The adoption of agricultural innovations: a review. Technol Forecast Soc Chang. 1993;43(3):215-39.

33. Knowler D, Bradshaw B. Farmers' adoption of conservation agriculture: a review and synthesis of recent research. Food Policy. 2007;32(1):25-48.

34. Kassie M, Zikhali P, Manjur K, Edwards S. Adoption of sustainable agriculture practices: evidence from a semi-arid region of Ethiopia. Nat Res Forum. 2009;33(3):189-98.

35. Prager K, Posthumus H. Socio-economic factors influencing farmers' adoption of soil conservation practices in Europe. In: Napier T, editor. Human dimensions of soil and water conservation: a global perspective. New York: Nova Science Publishers Inc; 2010. p. 203-23.

36. Asfaw S, Shiferaw B, Simtowe F, Lipper L. Impact of modern agricultural technologies on smallholder welfare: evidence from Tanzania and Ethiopia. Food Policy. 2012;37(3):283-95.
37. Rodríguez-Entrena M, Arriaza M. Adoption of conservation agriculture in olive groves: evidences from southern Spain. Land Use Policy. 2013:34:294-300.

38. Duflo E, Kremer M, Robinson J. How high are rates of return to fertilizer? Evidence from field experiments in Kenya. Am Econ Rev. 2008;98(2):482-8.

39. Barham BL, Foltz JD, Jackson-Smith D, Moon S. The dynamics of agricultural biotechnology adoption: lessons from series rBST use in Wisconsin, 1994-2001. Am J Agr Econ. 2004;86(1):61-72.

40. Ogada MJ, Nyangena W. Complementarity of inorganic fertilizers and improved maize varieties and farmer efficiency in maize production in Kenya. Afr Rev Econ Financ. 2019;11(1):76-100.

41. Kassie M, Jaleta M, Shiferaw B, Mmbando F, Mekuria M. Adoption of interrelated sustainable agricultural practices in smallholder systems: evidence from rural Tanzania. Technol Forecast Soc Chang. 2013;80(3):525-40.

42. Teklewold H, Kassie M, Shiferaw B. Adoption of multiple sustainable agricultural practices in Rural Ethiopia. J Agric Econ. 2013;64(3):597-623.

43. Massawe HJB. Landform and soil analysis for predicting distribution of plague reservoirs and vectors in Mavumo Area Lushoto District. Tanzania: Sokoine University of Agriculture; 2011.

44. Winowiecki L, Vågen T-G, Massawe B, Jelinski NA, Lyamchai C, Sayula G, Msoka E. Landscape-scale variability of soil health indicators: effects of cultivation on soil organic carbon in the Usambara mountains of Tanzania. Nutr Cycl Agroecosyst. 2016;105(3):263-74.

45. Ndakidemi PA, Semoka JMR. Soil fertility survey in Western Usambara mountains, Northern Tanzania1, 1 Project supported by the Norwegian Agency for Development Cooperation (NORAD), Tanzania. Pedosphere. 2006;16(2):237-44.

46. Feder G. Adoption of interrelated agricultural innovations: complementarity and the impacts of risk, scale, and credit. Am J Agr Econ. 1982;64(1):94-101.

47. Chib S, Greenberg E. Analysis of multivariate probit models. Biometrika. 1998;85(2):347-61.

48. Ochieng J, Kirimi L, Ochieng DO, Njagi T, Mathenge M, Gitau R, Ayieko M. Managing climate risk through crop diversification in rural Kenya. Clim Change. 2020;162(3):1107-25.

49. Recha JWM, Radeny MAO, Kinyangi J, Kimeli P, Atakos V, Lyamchai CRN, Sayula G. Climate-smart villages and progress in achieving household food security in Lushoto, Tanzania. CCAFS Info Note. CGIAR Research Program on Climate Change, Agriculture and Food Security (CCAFS) Copenhagen, Denmark. (2015) www ccafscgiarorg

50. Ogada MJ, Mwabu G, Muchai D. Farm technology adoption in Kenya: a simultaneous estimation of inorganic fertilizer and improved maize variety adoption decisions. Agric Food Econ. 2014;2(1):12.

51. Mzyece A, Ng'ombe JN. Does crop diversification involve a trade-off between technical efficiency and income stability for rural farmers? Evidence from Zambia. Agronomy. 2020;10(12):1875.

52. Ndiritu SW, Kassie M, Shiferaw B. Are there systematic gender differences in the adoption of sustainable agricultural intensification practices? Evidence from Kenya. Food Policy. 2014;49:117-27.

53. Kurgat BK, Lamanna C, Kimaro A, Namoi N, Manda L, RosenstockTS. Adoption of climate-smart agriculture technologies in Tanzania. Front Sustain Food Syst. 2020. https://doi.org/10.3389/fsufs.2020.00055.

54. Sheahan M, Barrett CB. Understanding the agricultural input landscape in sub-Saharan Africa: recent plot, household, and community-level evidence. World Bank Policy Research Paper 7014. Washington: World Bank; 2014.

\section{Publisher's Note}

Springer Nature remains neutral with regard to jurisdictional claims in published maps and institutional affiliations. 